\title{
Safening effect of bentazon on cloransulam-methyl and halosulfuron-methyl in dry bean
}

\author{
Nader Soltani", Christy Shropshire, Peter H. Sikkema \\ University of Guelph, Ridgetown Campus, Ontario, Canada; ${ }^{*}$ Corresponding Author: nsoltani@ridgetownc.uoguelph.ca
}

Received 16 January 2012; revised 26 February 2012; accepted 8 March 2012

\begin{abstract}
Bentazon, applied as a tankmix, has been shown to have the potential for reducing the injury from some POST herbicides. Field experiments were conducted in 2008 and 2009 at Exeter, ON and in 2009 at Ridgetown, ON to determine if the addition of bentazon reduces the injury from cloransulam-methyl or halosulfuron-methyl applied POST in black, cranberry, kidney and white beans. Bentazon added to cloransulammethyl reduced the level of injury 0 to $6 \%$ at 17.5 $\mathrm{g} \cdot \mathrm{ai} \cdot \mathrm{ha}^{-1}$ and 0 to $9 \%$ at $35 \mathrm{~g} \cdot \mathrm{ai} \cdot \mathrm{ha}^{-1}$ in dry bean. Bentazon added to halosulfuron-methyl reduced the level of injury as much as $4 \%$ at $35 \mathrm{~g} \cdot \mathrm{ai} \cdot \mathrm{ha}^{-1}$ and $6 \%$ at the $70 \mathrm{~g} \cdot \mathrm{ai} \cdot \mathrm{ha}^{-1}$. Bentazon added to cloransulam-methyl increased plant height as much as $3 \mathrm{~cm}$. The addition of bentazon to halosulfuron-methyl had no effect on the height of various market classes of dry bean. Bentazon added to cloransulam-methyl generally has no effect on seed moisture content in black and white bean but decreased seed moisture content of cranberry and kidney bean as much as $4 \%$. The addition of bentazon to halosulfuron-methyl caused no effect on seed moisture content of dry bean. Cloransulam-methyl caused a $7 \%$ to $18 \%$ reduction in dry bean yield compared to halosulfuron- methyl and $12 \%$ to $21 \%$ reduction in yield compared to bentazon. Bentazon added to cloransulam-methyl increased dry bean yield by 0.16 and $0.31 \mathrm{t} \cdot \mathrm{ha}^{-1}$ at Exeter (2009) and Ridgetown (2009) respectively. The addition of bentazon to halosulfuron-methyl had no effect on dry bean yield.
\end{abstract}

Keywords: Bentazon; Cloransulam-Methyl; Crop Injury; Halosulfuron-Methyl; Safening; Phaseolus Vulgaris; Sensitivity

\section{INTRODUCTION}

Dry bean (Phaseolus vulgaris L.) production is important to the economy in Ontario. In 2009, dry bean growers produced nearly 80,000 tonnes on approximately 40,000 hectares with a farm gate value of more than $\$ 51,000,000$ [1]. Weed control is one of the most critical production concerns as dry bean has short stature and thus is a poor competitor against weeds. The most prevalent and troublesome weeds in the region include Chenopodium album L. (common lambsquarter), Amaranthus retroflexus L. (redroot pigweed.), Abutilon theophrasti Medic. (velvetleaf), Ambrosia artemisiifolia L. (common ragweed), Sinapis arvensis L. (wild mustard), Polygonum spp. (smartweed), Solanum spp. (night-shades) and Setaria spp. (foxtails) [2]. Dry bean growers are constantly looking for herbicide options with a new mode of action that have an adequate margin of crop safety and provide consistent control of troublesome weeds in various market classes of dry beans.

Cloransulam-methyl is a triazolopyrimidine sulfonamide herbicide that controls several broadleaf weeds that occur in Ontario such as A. theophrasti, Xanthium strumarium L. (common cocklebur) and A. artemisiifolia [3]. Cloransulam-methyl inhibits acetolactate synthase (ALS), an important enzyme responsible for the synthesis of branched-chain amino acids isoleucine, leucine and valine in plants [3]. Cloransulam-methyl can be applied preemergence (PRE) and postemergence (POST) in bean [3]. It is readily translocated from roots to shoots and from shoots to roots causing rapid growth inhibition in susceptible plants [3]. Injury symptoms from cloransulam-methyl POST in susceptible weeds include growing point inhibition, chlorosis followed by necrosis, stunting, and complete death within 3 - 10 days [3]. Cloransulam-methyl is active at low doses, possesses low mammalian toxicity and is relatively soil immobile so it has little potential to contaminate groundwater and the environment [3].

Halosulfuron-methyl is a sulfonylurea herbicide that also inhibits acetolactate synthase [3]. Halosulfuron- 
methyl controls broadleaf weeds such as $A$. retroflexus, $A$. theophrasti, Polygonum persicaria L. (ladysthumb), X. strumarium and Cyperus esculentus L. (yellow nutsedge), including group resistant biotypes [3]. Halsosulfuronmethyl is readily taken up by both the roots and shoots of susceptible plants and is translocated throughout the plant causing rapid growth inhibition. Injury from halosulfuron in susceptible weeds includes chlorosis within 3 7 days, death of the growing point within 7 - 14 days and complete death of susceptible plants within $14-21$ days [3]. Similar to cloransulam-methyl, halosulfuron- methyl is relatively immobile in soil and is active at low doses so it has little potential to contaminate groundwater and the environment [3].

The few published studies on crop tolerance and weed control efficacy of cloransulam-methyl and halosulfuron-methyl in dry bean have shown crop injury with cloransulam-methyl and halosulfuron-methyl applied POST in some market classes of dry bean [4]. Herbicides such as bentazon have been shown to have the potential to reduce crop injury in dry beans or other crops when tank-mixed with injurious herbicides such as tritosulfuron, thifensulfuron, saflufenacil and imazethapyr [5-8]. In addition to its safening characteristics, bentazon is a selective benzothiadiazole POST herbicide that controls broadleaf weeds such as C. album, A. theophrasti, Portulaca oleracea L. (purslane), Raphanus raphanistrum L. (wild radish), Galinsoga ciliata (hairy galinsoga), Senecio vulgaris (common groundsel), Datura stramonium L. (jimsonweed), P. persicaria, Sinapis arvensis L., $X$. strumarium, Capsella bursa-pastoris (L.) Medic (shepherdspurse) and Stellaria media (L.) Vill. (common chickweed), including group II and $\mathrm{V}$ resistant biotypes $[2,3]$.

Currently there is little information on the safening effect of bentazon on cloransulam-methyl and halosulfuron-methyl applied POST in different market classes of dry beans. More information is needed on the tolerance of dry bean to the tank mixed combination of bentazon with cloransulam-methyl or halosulfuron-methyl. If crop tolerance is adequate, registration of this tank-mix would provide dry bean growers with an effective safe option for control of troublesome broadleaf weeds. The objecttive of this study was to determine if the addition of bentazon reduces the injury from cloransulam-methyl or halosulfuron-methyl applied POST in black, cranberry, kidney and white beans.

\section{MATERIALS AND METHODS}

Field experiments were conducted in 2008 and 2009 at the Huron Research Station, Exeter, Ontario and in 2009 at the University of Guelph, Ridgetown Campus, Ridgetown, Ontario. The soil at Exeter was a Brookston clay loam (Orthic Humic Gleysol, mixed, mesic and poorly drained) with $33 \%$ sand, $35 \%$ silt, $32 \%$ clay, $3.4 \%$ organic matter and $\mathrm{pH}$ of 7.9 in 2008 and $38 \%$ sand, $41 \%$ silt, $21 \%$ clay, $3.7 \%$ organic matter and $\mathrm{pH}$ of 7.8 in 2009. The soil at Ridgetown was Watford (Grey-Brown Brunisolic, mixed, mesic, sandy and imperfectly drained)-Brady (Gleyed Brunisolic Grey-Brown Luvisol, mixed, mesic, sandy and imperfectly drained) with 52\% sand, $28 \%$ silt, $20 \%$ clay, $5.9 \%$ organic matter and $\mathrm{pH}$ of 6.4 in 2009. Seedbed preparation consisted of autumn moldboard plowing followed by three passes with a field cultivator with rolling basket harrows in the spring.

The experiment at each site was arranged in a splitplot design with four replications. The main plots were herbicide treatments and the sub-plots were market classes of dry beans. Herbicide treatments are listed in Table 1. Plots consisted of four rows that were $3 \mathrm{~m}$ wide (4 rows spaced $0.75 \mathrm{~m}$ apart) and $10 \mathrm{~m}$ long at Exeter and $8 \mathrm{~m}$ long at Ridgetown. Within each plot, there was one row of black ("Black Velvet"), white ("T9905"), cranberry ("Etna") and kidney ("Redhawk") bean. Beans were planted to a depth of $5 \mathrm{~cm}$ on June 6, 2008 and June 4, 2009 at Exeter and June 2, 2009 at Ridgetown at a rate of 250,000 seeds $\cdot \mathrm{ha}^{-1}$ for black and white beans and 180,000 seeds $\cdot h^{-1}$ for cranberry and kidney beans.

Table 1. Herbicide and dose combinations for experimental treatments.

\begin{tabular}{|c|c|c|}
\hline & Treatment & $\begin{array}{c}\text { Dose } \\
\mathrm{g} \cdot \mathrm{ai} \cdot \mathrm{ha}^{-1}\end{array}$ \\
\hline 1 & Untreated check & 0 \\
\hline 2 & Cloransulam-methy $^{\mathrm{a}}$ & 17.5 \\
\hline 3 & Cloransulam-methyl $^{\mathrm{a}}$ & 35 \\
\hline 4 & Halosulfuron $^{\mathrm{b}}$ & 35 \\
\hline 5 & Halosulfuron $^{\mathrm{b}}$ & 70 \\
\hline 6 & Bentazon & 840 \\
\hline 7 & Bentazon & 1680 \\
\hline 8 & Cloransulam + bentazon $^{\mathrm{c}}$ & $17.5+840$ \\
\hline 9 & 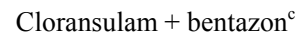 & $17.5+1680$ \\
\hline 10 & Cloransulam + bentazon $^{\mathrm{c}}$ & $35+840$ \\
\hline 11 & Cloransulam + bentazon $^{\mathrm{c}}$ & $35+1680$ \\
\hline 12 & Halosulfuron + bentazon & $35+840$ \\
\hline 13 & Halosulfuron + bentazon & $35+1680$ \\
\hline 14 & Halosulfuron + bentazon & $70+840$ \\
\hline 15 & Halosulfuron + bentazon & $70+1680$ \\
\hline
\end{tabular}

${ }^{\mathrm{a}}$ Included non-ionic surfactant $(0.25 \% \mathrm{v} / \mathrm{v})$ and $28 \%$ UAN $(2.5 \% \mathrm{v} / \mathrm{v})$; ${ }^{\mathrm{b}} \mathrm{In}-$ cluded non-ionic surfactant $(0.25 \% \mathrm{v} / \mathrm{v})$; ${ }^{\mathrm{c}}$ Included $28 \%$ UAN $(2.5 \% \mathrm{v} / \mathrm{v})$. 
Herbicide treatments were applied using a $\mathrm{CO}_{2}$-pressurized backpack sprayer calibrated to deliver $200 \mathrm{~L} \cdot \mathrm{ha}^{-1}$ at $240 \mathrm{kPa}$. The boom was $1.5 \mathrm{~m}$ long with four ultra-low drift nozzles (ULD120-02, Hypro, New Brighton, MN) spaced $50 \mathrm{~cm}$ apart. Treatments were applied 3 to 4 weeks after planting at the $2-3$ trifoliate dry bean leaf stage. All treatments including the non-treated control were maintained weed free by inter-row cultivation and hand hoeing as required during the growing season.

Crop injury was evaluated visually 1,2 and 4 weeks after treatment (WAT) using a scale of 0 to $100 \%$ where a rating of 0 was defined as no visible plant injury and a rating of 100 was defined as plant death. At 4 WAT, a 1 $\mathrm{m}$ section of row for each cultivar was hand harvested at the ground level, oven dried at $60^{\circ} \mathrm{C}$ to a constant moisture and the dry weight was recorded. At 5 WAT, ten plants per plot were randomly selected and the height from the soil surface to the highest growing point was measured. Yields were measured at crop maturity by hand-harvesting the remaining $9 \mathrm{~m}$ from each plot at Exeter and $7 \mathrm{~m}$ from each plot at Ridgetown and threshing in a plot combine. Crops were considered physically mature when $90 \%$ of the pods in the non-treated plots of each market class had turned from green to a golden colour. Dry beans were harvested at Exeter from Sept. 2 to Sept. 18 in 2008 and from Sept. 8 to Sept. 22 in 2009; and at Ridgetown on Sept. 16, 2009. All yields were adjusted to $18 \%$ moisture.

Data were analyzed using the PROC MIXED procedure of SAS (Release 9.2. Statistical Analysis Systems Institute, Cary, NC, USA) as a factorial [treatment (1 15) and market class (black, white, cranberry and kidney bean)]. Variances were partitioned into the random effects of locations, years, and years by locations, blocks within years by locations, and their interactions with fixed effects, and into the fixed effects of herbicide treatment, market class and herbicide by market class. Significance of random effects was tested using a Z-test of the variance estimate and fixed effects were tested using F-tests. Error assumptions of the variance analyses (random, homogeneous, normal distribution of error) were confirmed using residual plots and the ShapiroWilk normality test. To meet the assumptions of the variance analysis, percent injury at 1 WAT for Exeter 2008 and all injury 2 and 4 WAT were subjected to square root transformation [9]. Seed moisture content data were log transformed. Means were compared on the transformed scale and were converted back to the original scale for presentation of the results. Treatments were compared using planned contrasts as listed in Table 2. The Type I error was set at $\mathrm{P}<0.05$ for all statistical comparisons.

\section{RESULTS AND DISCUSSION}

Statistical analysis showed that environment by treatment by variety interaction was significant for all variables except moisture therefore environments could not be combined for most variables. The 2009 data could be combined for injury 1 and 2 WAT and height. All three environments had to be separated for injury 4 WAT, dry weight and yield. Where the treatment by variety interaction was significant, data was split into variety groups: black and white together; cranberry and kidney together.

Table 2. Contrasts planned for treatment comparisons.

\begin{tabular}{|c|c|c|}
\hline Contrast label & Contrast description & Treatments \\
\hline $\mathrm{C}$ vs $\mathrm{H}$ & cloransulam vs halosulfuron & 2,3 vs 4,5 \\
\hline $\mathrm{C}$ vs B & cloransulam vs bentazon & 2,3 vs 6,7 \\
\hline $\mathrm{H}$ vs $\mathrm{B}$ & halosulfuron vs bentazon & 4,5 vs 6,7 \\
\hline $\mathrm{C}$ vs $\mathrm{C}+\mathrm{B}$ & cloransulam vs cloransulam+bentazon & 2,3 vs $8,9,10,11$ \\
\hline $\mathrm{C}$ (low) vs $\mathrm{C}($ low $)+\mathrm{B}$ & cloransulam (low dose) vs cloransulam (low dose) + bentazon & 2 vs 8,9 \\
\hline $\mathrm{C}$ (high) vs $\mathrm{C}$ (high) $+\mathrm{B}$ & cloransulam (high dose) vs cloransulam (high dose) + bentazon & 3 vs 10,11 \\
\hline $\mathrm{C}$ vs $\mathrm{C}+\mathrm{B}($ low $)$ & cloransulam vs cloransulam + bentazon (low dose) & 2,3 vs 8,10 \\
\hline C vs C + B (high) & cloransulam vs cloransulam + bentazon (high dose) & 2,3 vs 9,11 \\
\hline $\mathrm{H}$ vs $\mathrm{H}+\mathrm{B}$ & halosulfuron vs halosulfuron + bentazon & 4,5 vs $12,13,14,15$ \\
\hline $\mathrm{H}($ low $)$ vs $\mathrm{H}($ low $)+\mathrm{B}$ & halosulfuron (low dose) vs halosulfuron (low dose) + bentazon & 4 vs 12,13 \\
\hline $\mathrm{H}$ (high) vs $\mathrm{H}$ (high) $+\mathrm{B}$ & halosulfuron (high dose) vs halosulfuron (high dose) + bentazon & 5 vs 14,15 \\
\hline $\mathrm{H}$ vs $\mathrm{H}+\mathrm{B}(\mathrm{low})$ & halosulfuron vs halosulfuron + bentazon (low dose) & 4,5 vs 12,14 \\
\hline $\mathrm{H}$ vs $\mathrm{H}+\mathrm{B}$ (low) & halosulfuron vs halosulfuron + bentazon (high dose) & 4,5 vs 13,15 \\
\hline
\end{tabular}


Shoot dry weight results were similar to plant height therefore only plant height results are discussed.

\subsection{Crop Injury}

Cloransulam-methyl applied POST caused more injury than halosulfuron-methyl or bentazon at 1, 2 and 4 WAT in dry bean (Table 3). There was little difference between bentazon doses ( 840 and $1680 \mathrm{~g} \cdot \mathrm{ai}^{\circ} \cdot \mathrm{ha}^{-1}$ ) on their safening effects on cloransulam-methyl. The addition of bentazon (doses combined) to cloransulam-methyl reduced the level of injury 0 to $6 \%$ at $17.5 \mathrm{~g} \cdot \mathrm{ai} \cdot \mathrm{ha}^{-1}$ and 0 to $9 \%$ at $35 \mathrm{~g} \cdot$ ai $\cdot \mathrm{ha}^{-1}$ in dry bean (Table 3 ). Generally, halosulfuron-methyl caused more injury than bentazon to dry bean. There was generally no difference between bentazon doses ( 840 or $1680 \mathrm{~g} \cdot \mathrm{ai}^{\mathrm{a}} \cdot \mathrm{ha}^{-1}$ ) on their safening effects on halosulfuron-methyl. The addition of bentazon (doses combined) to halosulfuron-methyl reduced the level of injury as much as $4 \%$ at $35 \mathrm{~g} \cdot \mathrm{ai} \cdot \mathrm{ha}^{-1}$ and $6 \%$ at the $70 \mathrm{~g} \cdot$ ai $^{\prime} \mathrm{ha}^{-1}$ (Table 3).

In other studies, cloransulam-methyl caused as much as $23 \%$ injury in black, cranberry, kidney and white bean, respectively $[4,11]$. Halosulfuron-methyl applied POST caused $7 \%$ to $13 \%$ injury in black, cranberry, kidney, otebo, pinto, SRM and white beans [10]. Stewart et al.
[12] reported up to $67 \%$ injury with halosulfuron-methyl applied POST at $35 \mathrm{~g} \cdot \mathrm{ai}^{-\mathrm{ha}^{-1}}$ and $86 \%$ injury at $70 \mathrm{~g} \cdot \mathrm{ai} \cdot$ $\mathrm{ha}^{-1}$ in adzuki bean. Other sulfonylurea herbicides such as thifensulfuron caused as much as $67 \%$ injury in adzuki bean (Stewart et al. 2010). Wall [13] found that thifensulfuron plus bentazon applied POST caused $\leq 50 \%$ injury in navy bean. Silvey et al. [14] reported 5\% injury from halosulfuron-methyl POST in snap bean (Phaseolus vulgaris L.). Other ALS inhibiting herbicides such imazethapyr POST did not injure pinto bean in Alberta and New Mexico $[15,16]$ but caused significant injury in studies conducted in Michigan, Nebraska and Wyoming $[5,17,18]$. Renner and Powell [17] reported that imazethapyr applied POST caused $20 \%$ injury in pinto bean. Soltani et al. [19] found as much as $44 \%$ injury in pinto and SRM bean with imazethapr. VanGessel et al. [20] found $0 \%$ to $33 \%$ injury to lima bean with imazamox plus bentazon depending on site, year and application dose. The addition of bentazon to ALS inhibiting herbicides also has been shown to reduce crop injury in dry bean. Bauer et al. [5] found as much as $20 \%$ reduction in crop injury to pinto bean when bentazon was tank-mixed with imazethapyr compared to imazethapyr alone. Wall [13] found as much as $14 \%$ less injury with in navy bean

Table 3. Contrasts comparing dry bean injury 1, 2 and 4 WAT for cloransulam-methyl (C) and halosulfuron-methyl (H) treatments alone or with the addition of bentazon (B) at Exeter and Ridgetown, $\mathrm{ON}^{\mathrm{a}}$.

\begin{tabular}{|c|c|c|c|c|c|c|c|c|}
\hline \multirow{4}{*}{ Treatment comparison } & \multicolumn{8}{|c|}{ Dry bean injury \% } \\
\hline & \multicolumn{3}{|c|}{$1 \mathrm{WAT}$} & \multirow{2}{*}{\multicolumn{2}{|c|}{2 WAT }} & \multirow{2}{*}{\multicolumn{3}{|c|}{4 WAT }} \\
\hline & \multicolumn{2}{|c|}{ E1 } & \multirow{2}{*}{$\mathrm{E} 2, \mathrm{R} 1$} & & & & & \\
\hline & Group 1 & Group 2 & & E1 & E2, R1 & E1 & E2 & $\mathrm{R}$ \\
\hline $\mathrm{C}$ vs $\mathrm{H}$ & 12 vs $4^{*}$ & 11 vs $6^{*}$ & 24 vs $11^{*}$ & 12 vs $2^{*}$ & 21 vs $7^{*}$ & 4 vs $1^{*}$ & 7 vs $3^{*}$ & 13 vs $6^{*}$ \\
\hline C vs B & 12 vs $0^{*}$ & 11 vs $3^{*}$ & 24 vs $4^{*}$ & 12 vs $2^{*}$ & 21 vs $1^{*}$ & 4 vs $0^{*}$ & 7 vs $0^{*}$ & 13 vs $0^{*}$ \\
\hline $\mathrm{H}$ vs B & 4 vs $0^{*}$ & 6 vs $3^{*}$ & 11 vs 4 & 2 vs 2 & 7 vs $1^{*}$ & 1 vs 0 & 3 vs $0^{*}$ & 6 vs $0^{*}$ \\
\hline $\mathrm{C}$ vs $\mathrm{C}+\mathrm{B}$ & 12 vs $9^{*}$ & 11 vs $10^{*}$ & 24 vs 20 & 12 vs $8^{*}$ & 21 vs 14 & 4 vs $2^{*}$ & 7 vs 6 & 13 vs $8^{*}$ \\
\hline $\mathrm{C}($ low) vs $\mathrm{C}($ low $)+\mathrm{B}$ & 9 vs $7^{*}$ & 9 vs 9 & 21 vs 16 & 7 vs 7 & 18 vs 11 & 3 vs $2^{*}$ & 6 vs 5 & 12 vs $6^{*}$ \\
\hline $\mathrm{C}$ (high) vs $\mathrm{C}$ (high) $+\mathrm{B}$ & 16 vs $10^{*}$ & 13 vs $10^{*}$ & 26 vs 24 & 18 vs $9^{*}$ & 24 vs 17 & 5 vs $3^{*}$ & 7 vs 7 & 14 vs $10^{*}$ \\
\hline $\mathrm{C}$ vs $\mathrm{C}+\mathrm{B}$ (low) & 12 vs $9^{*}$ & 11 vs 10 & 24 vs 18 & 12 vs $8^{*}$ & 21 vs 13 & 4 vs $2^{*}$ & 7 vs $5^{*}$ & 13 vs $8^{*}$ \\
\hline $\mathrm{C}$ vs $\mathrm{C}+\mathrm{B}$ (high) & 12 vs $8^{*}$ & 11 vs $9^{*}$ & 24 vs 21 & 12 vs $7^{*}$ & 21 vs 16 & 4 vs $2^{*}$ & 7 vs 6 & 13 vs $8^{*}$ \\
\hline $\mathrm{H}$ vs $\mathrm{H}+\mathrm{B}$ & 4 vs $2^{*}$ & 6 vs 5 & 11 vs 7 & 2 vs $3^{*}$ & 7 vs $3^{*}$ & 1 vs 1 & 3 vs $4^{*}$ & 6 vs $2^{*}$ \\
\hline $\mathrm{H}($ low $)$ vs $\mathrm{H}($ low $)+\mathrm{B}$ & 3 vs $1^{*}$ & 6 vs $4^{*}$ & 8 vs 6 & 2 vs $3^{*}$ & 5 vs 2 & 0 vs 1 & 3 vs $4^{*}$ & 4 vs $0^{*}$ \\
\hline $\mathrm{H}$ (high) vs $\mathrm{H}$ (high) $+\mathrm{B}$ & 6 vs $2^{*}$ & 6 vs 6 & 15 vs 8 & 3 vs 3 & 10 vs 4 & 1 vs 0 & 4 vs 5 & 9 vs $3^{*}$ \\
\hline $\mathrm{H}$ vs $\mathrm{H}+\mathrm{B}$ (low) & 4 vs $2^{*}$ & 6 vs 6 & 11 vs 6 & 2 vs $3^{*}$ & 7 vs $2^{*}$ & 1 vs 1 & 3 vs $4^{*}$ & 6 vs $0^{*}$ \\
\hline H vs $\mathrm{H}+\mathrm{B}$ (high) & $4 \mathrm{vs} 2^{*}$ & 6 vs 5 & 11 vs 8 & $2 \mathrm{vs} 3^{*}$ & 7 vs 4 & 1 vs 1 & 3 vs $4^{*}$ & 6 vs $3^{*}$ \\
\hline
\end{tabular}

*Denotes significance at $\mathrm{P}<0.05$; ${ }^{\mathrm{a}}$ Abbreviations: WAT, weeks after treatment; E1, Exeter 2008; E2, Exeter 2009; Group 1, black and white bean; Group 2, cranberry and kidney bean; R, Ridgetown 2009. 
with postemergence application of imazethapyr (50 g.ai$\left.\mathrm{ha}^{-1}\right)$ tank-mixed with bentazon $\left(600 \mathrm{~g} \cdot \mathrm{ai} \cdot \mathrm{ha}^{-1}\right)$ compared with imazethapyr alone.

\subsection{Plant Height}

Generally dry bean growers do not like to see a reduction in plant height as shorter plants result in increased bean shatter losses at the cutter bar of the combine during harvest which may can result in significant yield losses. Cloransulam-methyl (doses combined) reduced plant height $4 \mathrm{~cm}$ compared to halosulfuron-methyl (doses combined) and as much as $6 \mathrm{~cm}$ compared to bentazon (doses combined) in the market classes of dry beans evaluated (market classes combined) (Table 4). There was generally no difference between bentazon doses (840 and $1680 \mathrm{~g} \cdot \mathrm{ai} \cdot \mathrm{ha}^{-1}$ ) on their safening effects on cloransulam-methyl. The addition of bentazon at 840 or $1680 \mathrm{~g} \cdot \mathrm{ai} \cdot \mathrm{ha}^{-1}$ to cloransulam-methyl at 17.5 or 35 $\mathrm{g} \cdot \mathrm{ai} \cdot \mathrm{ha}^{-1}$ increased plant height as much as $3 \mathrm{~cm}$. In other studies, cloransulam-methyl caused no decrease in plant height of the different market classes of dry bean except when applied PRE which reduced black bean height $27 \%$ and cranberry bean height $25 \%$ at $70 \mathrm{~g} \cdot \mathrm{ha}^{-1}$ and reduced white bean height $19 \%$ at $35 \mathrm{~g} \cdot \mathrm{ha}^{-1}$ and $37 \%$ at $70 \mathrm{~g} \cdot \mathrm{ha}^{-1}$ [4]. Other ALS-inhibiting herbicides such as imazethapyr POST have been reported to reduce plant height as much as $21 \%$ in dry bean $[19,20]$. Imazamox has also been reported to reduce dry bean height by 5 to $8 \mathrm{~cm} \mathrm{[21].}$

Halosulfuron-methyl (doses combined) reduced plant height as much as $2 \mathrm{~cm}$ compared to bentazon (doses combined) with dry beans evaluated (market classes combined). The addition of bentazon to halosulfuronmethyl at either dose had no effect on plant height of the various market classes of dry bean evaluated (Table 4). Other studies have shown significant plant height reducetion from sulfonylurea herbicides in dry bean. Thifensulfuron applied POST decreased plant height 15\% to $57 \%$ in dry bean [22]. Chlorimuron applied POST decreased plant height as much as $36 \%$ in dry bean [22]. Thifensulfuron and halosulfuron-methyl also caused significant reduction in height of adzuki bean [12].

\subsection{Seed Moisture Content}

Seed moisture content is indicative of maturity and is critical in dry bean production as high seed moisture content at harvest can increase spoilage due to bacterial and fungal diseases, staining, or increased drying costs and can result in dockage at the point of sale. Cloransulam-methyl (doses combined) caused a delay in maturity compared to halosulfuron-methyl (doses combined) in cranberry and kidney bean as indicated by increased seed moisture content of $1.8 \%$ (Table 5). However, there was no difference in seed moisture content of black and white
Table 4. Contrasts comparing dry bean height for cloransulam-methyl $(\mathrm{C})$ and halosulfuron-methyl $(\mathrm{H})$ treatments alone or with the addition of bentazon (B) at Exeter and Ridgetown, $\mathrm{ON}^{\mathrm{a}}$.

\begin{tabular}{ccc}
\hline \multirow{2}{*}{ Treatment comparison } & \multicolumn{2}{c}{ Height cm } \\
\cline { 2 - 3 } & E1 & E2, R1 \\
\hline C vs H & 59 vs $63^{*}$ & 57 vs $61^{*}$ \\
C vs B & 59 vs $64^{*}$ & 57 vs $63^{*}$ \\
H vs B & 63 vs 64 & 61 vs $63^{*}$ \\
C vs C + B & 59 vs 59 & 57 vs $60^{*}$ \\
C (low) vs C (low) + B & 61 vs 59 & 58 vs $61^{*}$ \\
C (high) vs C (high) + B & 57 vs 59 & 56 vs $58^{*}$ \\
C vs C + B (low) & 59 vs 59 & 57 vs $60^{*}$ \\
C vs C + B (high) & 59 vs 59 & 57 vs $59^{*}$ \\
H vs H + B & 63 vs 62 & 61 vs 61 \\
H (low) vs H (low) + B & 63 vs 62 & 61 vs 62 \\
H (high) vs H (high) + B & 63 vs 61 & 60 vs 60 \\
H vs H + B (low) & 63 vs 62 & 61 vs 62 \\
H vs H + B (low) & 63 vs 62 & 61 vs 60 \\
\hline
\end{tabular}

${ }^{*}$ Denotes significance at $\mathrm{P}<0.05$; ${ }^{\mathrm{a}}$ Abbreviations: E1, Exeter 2008; E2, Exeter 2009; R, Ridgetown 2009.

bean. Cloransulam-methyl (doses combined) increased seed moisture content $0.4 \%$ in black and white bean and $2.5 \%$ in cranberry and kidney bean compared to bentazon (doses combined). The addition of bentazon at 840 or $1680 \mathrm{~g} \cdot \mathrm{ai} \cdot \mathrm{ha}^{-1}$ to cloransulam-methyl at 17.5 or 35 $\mathrm{g} \cdot \mathrm{ai} \cdot \mathrm{ha}^{-1}$ generally has no effect on seed moisture content of black and white bean but decreased seed moisture content of cranberry and kidney bean as much as 4\% (Table 5). When doses were combined halosulfuron-methyl had no effect on seed moisture content compared with bentazon in dry beans evaluated. The addition of bentazon at 840 or $1680 \mathrm{~g} \cdot \mathrm{ai} \cdot \mathrm{ha}^{-1}$ to halosulfuron-methyl at 35 or 70 $\mathrm{g} \cdot \mathrm{ai} \cdot \mathrm{ha}^{-1}$ also caused no significant effect on seed moisture content of black, white, cranberry and kidney bean (Table 5). In other studies, cloransulam-methyl increased seed moisture content $5.6 \%, 4.2 \%$ and $4.8 \%$ in black, cranberry and white bean, respectively [4]. In this study, there was differences in visible injury and seed moisture content of group 1 (black and white bean) and group 2 (cranberry and kidney bean) when treated with the POST herbicides evaluated. This is similar to other studies that have shown differential sensitivity of market classes of dry beans to other herbicides [5,11,18,23,24].

\subsection{Yield}

Cloransulam-methyl (doses combined) caused $7 \%$ to 
Table 5. Contrasts comparing dry bean seed moisture and yield for cloransulam-methyl $(\mathrm{C})$ and halosulfuron-methyl $(\mathrm{H})$ treatments alone or with the addition of bentazon (B) at Exeter and Ridgetown, $\mathrm{ON}^{\mathrm{a}}$.

\begin{tabular}{|c|c|c|c|c|c|}
\hline \multirow{2}{*}{ Treatment comparison } & \multicolumn{2}{|c|}{ Moisture \% } & \multicolumn{3}{|c|}{ Yield $t \cdot h a^{-1}$} \\
\hline & Group 1 & Group 2 & E1 & E2 & $\mathrm{R}$ \\
\hline $\mathrm{C}$ vs H & 20.3 vs 20.1 & 20.4 vs $18.6^{*}$ & 2.42 vs $2.86^{*}$ & $2.20 \mathrm{vs} 2.37^{*}$ & 1.99 vs $2.42^{*}$ \\
\hline C vs B & 20.3 vs $19.9^{*}$ & 20.4 vs $17.9^{*}$ & 2.42 vs $3.00^{*}$ & 2.20 vs $2.50^{*}$ & 1.99 vs $2.53^{*}$ \\
\hline $\mathrm{H}$ vs B & 20.1 vs 19.9 & 18.6 vs 17.9 & 2.86 vs 3.00 & 2.37 vs 2.50 & 2.42 vs 2.53 \\
\hline $\mathrm{C}$ vs $\mathrm{C}+\mathrm{B}$ & 20.3 vs 20.2 & 20.4 vs $17.2^{*}$ & 2.42 vs 2.46 & $2.20 \mathrm{vs} 2.36^{*}$ & 1.99 vs $2.30^{*}$ \\
\hline $\mathrm{C}$ (low) vs $\mathrm{C}($ low) $+\mathrm{B}$ & 20.2 vs 20.0 & 19.3 vs $16.9^{*}$ & 2.64 vs 2.52 & 2.21 vs 2.39 & 2.04 vs $2.48^{*}$ \\
\hline $\mathrm{C}$ (high) vs $\mathrm{C}$ (high) $+\mathrm{B}$ & 20.5 vs 20.4 & 21.5 vs $17.5^{*}$ & 2.21 vs $2.41^{*}$ & 2.18 vs 2.32 & 1.95 vs 2.13 \\
\hline $\mathrm{C}$ vs $\mathrm{C}+\mathrm{B}$ (low) & 20.3 vs $20.0^{*}$ & 20.4 vs $17.3^{*}$ & 2.42 vs 2.43 & 2.20 vs $2.36^{*}$ & 1.99 vs $2.29^{*}$ \\
\hline C vs C + B (high) & 20.3 vs 20.4 & 20.4 vs $17.2^{*}$ & 2.42 vs 2.50 & 2.20 vs $2.35^{*}$ & 1.99 vs $2.31^{*}$ \\
\hline $\mathrm{H}$ vs $\mathrm{H}+\mathrm{B}$ & 20.1 vs 20.0 & 18.6 vs 17.2 & 2.86 vs 2.89 & 2.37 vs 2.42 & 2.42 vs 2.33 \\
\hline $\mathrm{H}$ (low) vs H (low) + B & 19.9 vs 20.1 & 18.5 vs 17.3 & 2.89 vs 2.91 & 2.41 vs 2.43 & 2.50 vs 2.23 \\
\hline $\mathrm{H}$ (high) vs $\mathrm{H}$ (high) + B & 20.2 vs 19.9 & 18.7 vs 17.2 & 2.83 vs 2.87 & 2.33 vs 2.41 & 2.34 vs 2.42 \\
\hline $\mathrm{H}$ vs $\mathrm{H}+\mathrm{B}$ (low) & 20.1 vs 20.1 & 18.6 vs 17.1 & 2.86 vs 2.85 & 2.37 vs 2.45 & 2.42 vs 2.34 \\
\hline $\mathrm{H}$ vs $\mathrm{H}+\mathrm{B}$ (low) & 20.1 vs 19.8 & 18.6 vs 17.4 & 2.86 vs 2.94 & 2.37 vs 2.39 & 2.42 vs 2.32 \\
\hline
\end{tabular}

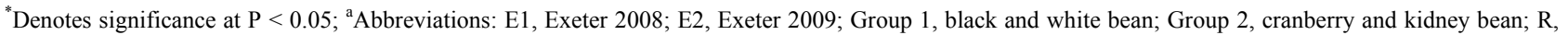
Ridgetown 2009.

$18 \%$ reduction in the yield of black, white, cranberry and kidney bean (market classes combined) compared to halosulfuron-methyl (doses combined) (Table 5). Cloransulam-methyl (doses combined) also caused $12 \%$ to $21 \%$ reduction in dry bean yield compared to bentazon (doses combined). The addition of bentazon slightly safened cloransulam-methyl however dry bean yield reductions still ranged from $0 \%$ to $18 \%$ depending on cloransulammethyl and bentazon doses and location (Table 5). With doses combined halosulfuron-methyl had no effect on dry bean yield compared with bentazon. Also, the addition of bentazon at 840 or $1680 \mathrm{~g} \cdot \mathrm{ai} \cdot \mathrm{ha}^{-1}$ to halosulfuronmethyl at 35 or $70 \mathrm{~g} \cdot \mathrm{ai} \cdot \mathrm{ha}^{-1}$ caused no significant effect on the yield of black, white, cranberry and kidney bean (Table 5). In other studies, cloransulam-methyl caused no decrease in yield of various market classes of dry bean except for black bean which was reduced $29 \%$ [4]. Other ALS-inhibiting herbicide herbicides such as imazethapyr caused no reduction in yield of pinto bean [15]. However, in other studies imazethapyr reduced yield as much as $25 \%$ in some market classes of dry bean [5, 19,25]. The addition of bentazon to other ALS inhibiting herbicide has been shown to have no effect on dry bean yield in some studies. Bauer et al. [5] found no effect in yield of pinto bean when bentazon was tank-mixed with imazethapyr compared to imazethapyr alone. Wall [13] also found no effect in yield of navy bean when bentazon was tank-mixed with imazethapyr compared to imaze- thapyr alone. Blackshaw et al. [21] also found no difference in yield of dry bean when bentazon was tankmixed with imazethapyr compared to imazethapyr alone.

\section{CONCLUSION}

Based on this research, cloransulam-methyl causes unacceptable crop injury and reduction in plant height, shoot dry weight and yield of black, white, cranberry and kidney bean. The addition of bentazon slightly safens cloransulam-methyl in dry bean under some environmental conditions however, the safening effects do not always provide an adequate margin of crop safety for dry bean. Halosulfuron-methyl applied POST alone and in combination with bentazon caused some early injury in dry bean but plants recovered later in the season with no adverse effect on dry bean plant height, shoot dry weight, seed moisture content and yield. Generally, the addition of bentazon to halosulfuron-methyl caused no adverse effect on plant height, seed moisture content and yield of black, white, cranberry and kidney bean. Additional research is needed to determine if cultivars within a market class of dry beans differ in their response to cloransulam-methyl, halosulfuron-methyl and their tankmix with bentazon.

\section{ACKNOWLEDGEMENTS}

We would like to acknowledge Todd Cowan for his expertise and 
technical assistance in these studies. Funding for this project was provided by the Ontario White Bean Producers, Ontario Coloured Bean Growers Association and CanAdvance.

\section{REFERENCES}

[1] McGee, B. (2010) Estimated area, yield, production and farm value of specified field crops, Ontario, 2001-2010. Ontario Ministry of Agriculture and Food and Rural Affairs.

http://www.omafra.gov.on.ca/english/stats/crops/estimate metric.html

[2] Ontario Ministry of Agriculture, Food and Rural Affairs (2010) Guide to weed control. Publication 75, Toronto.

[3] Senseman, S.A. (2007) Herbicide handbook. 9th Edition, Champaign.

[4] Soltani, N., Shropshire C. and Sikkema P.H. (2010) Tolerance of black, cranberry, kidney, and white bean to cloransulam-methyl. Weed Biology and Management, 10, 33-39. doi:10.1111/j.1445-6664.2010.00364.x

[5] Bauer, T.A., Renner, K.A., Penner, D. and Kelly, J.D. (1995) Pinto bean (Phaseolus vulgaris) varietal tolerance to imazethapyr. Weed Science, 43, 417-424.

[6] Lycan, D.W. and Hart, S.E. (1999) Physiological response of soybean (Glycine max) and two weed species to thifensulfuron and bentazon combinations. Weed Science, 47, 143-148.

[7] Moran, M., Sikkema, P.H., Hall, J.C. and Swanton, C.J. (2011) Sodium safens saflufenacil applied postemergence to corn (Zea mays). Weed Science, 59, 4-13. doi:10.1614/WS-D-10-00051.1

[8] Weinberg, T., Stephenson, G.R., McLean, M.D., Satchivi, N.M. and Hall, J.C. (2007) Basis for antagonism by sodium bentazon of tritosulfuron toxicity to white bean (Phaseolus vulgaris L.). Journal of Agricultural and Food Chemistry, 55, 2268-2275. doi:10.1021/jf062633o

[9] Bartlett, M.S. (1947) The use of transformations. Biometrics, 3, 39-52. doi:10.2307/3001536

[10] Soltani, N., Nurse, R.E., Shropshire, C. and Sikkema, P.H. (2009) Effect of halosulfuron applied preplant incorporated, preemergence, and postemergence on dry bean. Weed Technology, 23, 535-539. doi:10.1614/WT-09-047.1

[11] Soltani, N. and Sikkema, P.H. (2005) White bean (phaseolus vulgaris) tolerance to preplant-incorporated herbicides. Weed Biology and Management, 5, 35-38. doi:10.1111/j.1445-6664.2005.00153.x

[12] Stewart, C.L., Nurse, R.E., Gillard, C. and Sikkema, P.H. (2010) Tolerance of adzuki bean to preplant-incorporated, pre-emergence, and post-emergence herbicides in Ontario, Canada. Weed Biology and Management, 10, 40-47. doi:10.1111/j.1445-6664.2010.00365.x

[13] Wall, D.A. (1995) Bentazon tank-mixtures for improved redwood pigweed (Amaranthus retroflexus) and common lambsquarters (Chenopodium album) control in navy beans (Phaseolus vulgaris). Weed Technology, 9, 610616.

[14] Silvey, B.D., Mitchem, W.E., Macrae, A.W. and Monks, D.W. (2006) Snap bean (Phaseolus vulgaris) tolerance to halosulfuron PRE, POST, or PRE followed by POST. Weed Technology, 20, 873-876. doi:10.1614/WT-05-046.1

[15] Arnold, N.R., Murray, W.M., Gregory, J.E. and Smeal, D. (1993) Weed control in pinto beans (Phaseolus vulgaris) with imazethapyr combinations. Weed Technology, 7, 361364.

[16] Blackshaw, R.E. and Esau, R. (1991) Control of annual broadleaf weeds in pinto beans (Phaseolus vulgaris). Weed Technology, 5, 532-538.

[17] Renner, K.A. and Powell, G.E. (1992) Responses of navy bean (Phaseolus vulgaris) and wheat (Triticum aestivum) grown in rotation to clomazone, imazethapyr, bentazon, and aciflurofen. Weed Science, 40, 127-133.

[18] Wilson, R.G. Jr. and Miller, S.D. (1991) Dry edible bean (Phaseolus vulgaris) responses to imazethapyr. Weed Technology, 5, 22-26.

[19] Soltani, N., Nurse, R.E., Robinson, D.E. and Sikkema, P.H. (2008) Response of pinto and Small Red Mexican bean to postemergence herbicides. Weed Technology, 22, 195-199. doi:10.1614/WT-07-091.1

[20] VanGessel, J.M., Monks, W.D. and Quintin, R.J. (2000) Herbicides for potential use in lima bean (Phaseolus lunatus) production. Weed Technology, 14, 279-286. doi:10.1614/0890-037X(2000)014[0279:HFPUIL]2.0.CO $; 2$

[21] Blackshaw, R.E., Molnar, J.L., Muendel, H., Saindon, G. and Xiangju L. (2000) Integration of cropping practices and herbicides improves weed management in dry beans (Phaseolus vulgaris). Weed Technology, 14, 327-336. doi:10.1614/0890-037X(2000)014[0327:IOCPAH]2.0.CO ;2

[22] Sikkema, P.H., Soltani N., Shropshire, C. and Cowan. T. (2004) Tolerance of white beans to postemergence broadleaf herbicides. Weed Technology, 18, 893-901. doi:10.1614/WT-03-043R3

[23] Soltani, N., Bowley, S. and Sikkema P.H. (2005) Responses of black and cranberry beans (Phaseolus vulgaris) to postemergence herbicides. Crop Protection, 24, 15-21. doi:10.1016/j.cropro.2004.06.003

[24] Urwin, C.P., Wilson R.G. and Mortensen, D.A. (1996) Responses of dry edible bean (Phaseolus vulgaris) cultivars to four herbicides. Weed Technology, 10, 512-518.

[25] Blackshaw, R.E. and Saindon, G. (1996) Dry bean (Phaseolus vulgaris) tolerance to imazethapyr. Canadian Journal of Plant Science, 76, 915-919.

doi:10.4141/cjps96-153 